\title{
Description of a practice model for pharmacist medication review in a general practice setting
}

\author{
Mette BRANDT, Jesper HALLAS, Trine GRAABÆE, Anton POTTEGÅRD. \\ Received (first version): $15-$ Feb-2014 \\ Accepted: 21-Aug-2014
}

\begin{abstract}
${ }^{*}$
Background: Practical descriptions of procedures used for pharmacists' medication reviews are sparse.

Objective: To describe a model for medication review by pharmacists tailored to a general practice setting. Methods: A stepwise model is described. The model is based on data from the medical chart and clinical or laboratory data. The medication review focuses on the diagnoses of the patient instead of the individual drugs. Patient interviews are not part of the model. The model was tested in a pilot study by conducting medical reviews on 50 polypharmacy patients (i.e. receiving 7 or more drugs for regular use).

Results: The model contained seven main steps. Information about the patient and current treatment was collected in the first three steps, followed by identification of possible interventions related to either diagnoses or drugs in the fourth and fifth step. The sixth and seventh step concerned the reporting of interventions and the considerations of the GPs. 208 interventions were proposed among the 50 patients. The acceptance rate among the GPs was $82 \%$. The most common

interventions were lack of clinical or laboratory data $(n=57$, $27 \%$ ) and drugs that should be discontinued as they had no indication ( $n=47,23 \%)$. Most interventions were aimed at cardiovascular drugs.

Conclusion: We have provided a detailed description of a practical approach to pharmacists' medication review in a GP setting. The model was tested and found to be usable, and to deliver a medication review with high acceptance rates.
\end{abstract}

Keywords: Pharmaceutical Services; Professional Practice; Pharmacists; General Practitioners; DrugRelated Side Effects and Adverse Reactions; Drug Therapy; Denmark

\section{INTRODUCTION}

The term 'medication review' does not have a single well-defined meaning and is often found to include a wide range of interventions, from technical prescription review over interventions aimed at patient compliance to comprehensive medication management strategies. ${ }^{1-3}$ In studies of the effect of medication reviews, the tools used to perform the actual 'medication reviews' are often vaguely described or not described at all. ${ }^{3-5}$ A few validated tools to support medication reviews have been developed, such as the STOPP \& START-criteria by Gallagher et al. ${ }^{6}$ or the Medication Appropriateness Index (MAI) by Hanlon et al. ${ }^{7}$ The process of performing a medication review should, however, not only be a one-track search for inappropriate use of selected high-risk drugs, a reconciliation of medicine lists, or a search for cost-savings. Rather, a full medication review should ensure that all drugs on a patient's list of medication are assessed, and that every diagnosis is treated according to guidelines, e.g. taking comorbidity and specific patient characteristics into consideration. ${ }^{3}$ While such considerations may be expressed on a general level $^{3}$, detailed descriptions and procedures for medication review is lacking. Such procedures should clearly outline how to conduct a medication review, among other things taking into consideration the setting, as the data sources differ widely between e.g. a pharmacy and hospital setting. No single procedure will ever be universally accepted as a gold standard or a one-size-fits-all solution, nor should it be. A discussion of the procedures used by clinical pharmacists is, however, important in order to ensure a continuous development of the quality of the pharmaceutical services offered to patients.

This paper describes a practice model for pharmacist's medication review, tailored to the general practice setting. The model includes collaboration with the general practitioner (GP) but does not include a patient interview, and was tested in a pilot study by conducting medication reviews on 50 polypharmacy patients i.e. receiving 7 or more drugs for regular use.

\section{METHODS}

\section{The general practice setting}

The GPs in Denmark are part of the primary healthcare sector. A Danish GP is a private entrepreneur, but running business under contract with the Danish authorities. Every citizen is listed by one GP. The citizens have free access to consultation and treatment from the general \footnotetext{
Odense C; \& Department of Clinical Chemistry \&
Pharmacology, Odense University Hospital. Odense C (Denmark). apottegaard@health.sdu.dk

Mette BRANDT. MSc Pharm. Clinical Pharmacology, Odense C; \& Capital Region Pharmacy, Clinical (Denmark).mette.brandt@regionh.dk

Institute of Public Health, University of Southern Denmark. Odense C; \& Department of Clinical Chemistry \& (Denmark).jhallas@health.sdu.dk

Trine GRAAB/EK. MSc Pharm. Clinical Pharmacology, Institute of Public Health, University of Southern Denmark. Anton POTTEGARD. MSc Pharm. Clinical Pharmacology, Institute of Public Health, University of Southern Denmark.
} 
practitioner by which they are listed. Expenses are paid via taxes and the GP is usually the first contact for patients in need of medical services. Commonly, a Danish general practice consists of 1-5 doctors with one or more secretaries and one or more nurses employed. Some practices also have established collaboration with pharmacists.

\section{The model}

The model is divided into seven main steps (Figure 1). The first three steps focus on collecting information about the patient, while the fourth and fifth steps identify drug-related problems. The sixth and seventh steps concern the reporting of interventions and the GP's consideration.

The overall focus of the model is the patient and the patient's diagnoses as a whole. As such, the model can be regarded as patient-centered, as opposed to models focusing on the single drug/prescription. ${ }^{3} \mathrm{~A}$ patient interview is not part of the model.

\section{COLLECTING INFORMATION (STEP 1-3)}

The first step of the model was to read the last year of the patient's electronic health records, i.e. the medical chart, often including information on lifestyle factors such as smoking or alcohol use and information on drug allergies, along with clinical and laboratory data. The medical chart is specific for the
GP and only information known by the GP can be found in the system. If one year contained less than 20 entries, the latest 20 entries were read instead. Medical charts were always read chronologically. The patient's initials, birthday, most recently measured blood pressure (BP) and estimated glomerular filtration rate (GFR) were registered along with all registered diagnoses that would be expected to require a pharmacological treatment.

In the second step, the current pharmacological regimen was retrieved from the GP's lists of established prescription drugs along with their respective indication for treatment.

In the third step, the list of diagnoses was reconciled with the list of the current pharmacological treatment. This was accomplished by deciding whether the presence of each drug was accounted for by one of the diagnoses. For each patient, a list of the drugs that did not match a corresponding diagnosis was compiled. To reduce the risk of the pharmacist intervening towards wellindicated treatment, the patient's medical chart and discharge summaries were then re-read, this time looking back five years starting with the oldest entry. Note that this was only done if one or more drugs had no apparent indication. Diagnoses identified in this way were added to the list of diagnoses.

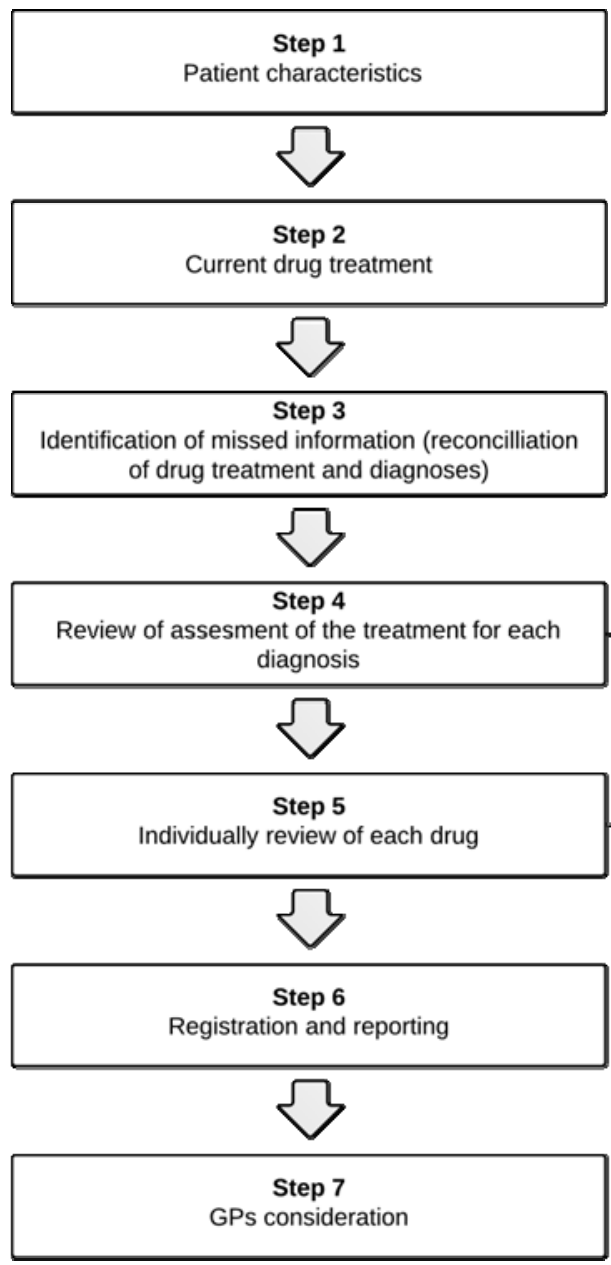

Q1 - Has the treatment goal been achieved?

Q2 - Is the current Drug therapy in aggreement with current treatment guidelines?

Q1 - Is the indication for treatment lacking?

Q2 - Are there specific patient characteristics or diagnoses which mean that this drug is inappropriate for this particular patient?

Q3 - Does laboratory data sugest adverse effects?

Q4 - Is there unnecessary duplicate treatment or drug-drug interactions?

Q5 - Are there signs of adverse effects that ought to be treated by add-on therapy or lead to a change in therapy?

Q6 - Are there any relevant price alternatives?

Q7 - Can the drug regimen be made simpler, e.g. by introducing combination therapy or prolonged-release formulations?

Figure 1. Simplified model for pharmacists' medication review in a general practice setting. 


\section{IDENTIFICATION OF INTERVENTIONS (STEP 4- 5)}

The fourth step focused on the diagnoses. First, treatment goals were set for each diagnosis using guidelines for the individual disease, e.g. target HbA1c-levels for diabetic patients or TSH-levels for patients with hypothyreoisis.

Each diagnosis was then reviewed asking two questions. The first question was: Has the treatment goal been achieved? This was assessed by checking clinical data, laboratory data and medical charts. If the treatment goals had not been met, the pharmacist suggested means to do so, e.g. by changing therapy, adding new therapy or changing dosing of existing therapy. If the necessary data were not available, e.g. blood pressure or $\mathrm{HbA} 1 \mathrm{c}$ had not been measured, the GP was asked to perform additional tests. The second question was: Is the current drug therapy in agreement with current treatment guidelines? The pharmacist intervened if any discrepancies were identified, e.g. missing beta-blocker or statin in a patient with a previous myocardial infarction or use of incorrect dosages, either insufficiently or excessively.

The fifth step of the model consisted of an individual review of each drug. For each drug, the pharmacist asked seven questions. The seven questions are given in the rightmost part of Figure 1.

\section{REGISTRATION AND REPORTING (STEP 6-7)}

The sixth step of the model concerned the registration and reporting of identified problems. Registrations were divided into two categories of interventions: interventions related to the diagnosis (identified during step 4) and interventions related to the individual drug (identified during step 5).

The diagnosis-related problems included: a) lack of relevant clinical or laboratory data in order to assess treatment goals, where the GP was encouraged to make additional testing; b) choice of wrong drug according to guidelines and c) treatment goals not met. The latter two were resolved by suggesting change to another drug, discontinuation of current drug treatment, add-on treatment and/or change of dosage due to super-/subtherapeutic dosage levels.

The drug-related problems included: a) missing diagnosis; b); patient characteristics conflicting with the given drug; c) missing or alarming laboratory data; d) duplicate treatment or drug-druginteractions; e) side-effects; f) less expensive alternatives and g) unnecessarily complicated dosage regimens. If no relevant diagnosis was identified, the treatment was suggested discontinued. If patient characteristics conflicted with the given drug or laboratory data were found alarming, it was suggested to change the dosage regimen, change to another drug or discontinue treatment. Missing laboratory data resulted in a suggestion to make additional testing. In case of duplicate treatment or drug-drug interactions, it was suggested to change to another drug or discontinue treatment. In case of side effects to necessary treatment, add-on treatment was suggested. If a less costly alternative was available, defined by a cost-saving of a minimum of 5.0DKK (corresponds to approximately $0.6 E U R$ ) per day with no loss of efficacy, it was suggested to change to another drug. If it were possible to reduce the number of daily dosages, it was suggested to change dosage regimen or change to another drug.

Each intervention was substantiated by a short account of the relevance of this particular intervention for this particular patient, i.e. the intervention always included patient-specific information. The intervention furthermore included a reference to the relevant treatment guideline and a detailed description of how the GP should act, e.g. the appropriate way to discontinue current treatment or initiate new treatment. All comments and proposed interventions regarding the patient's medical treatment were registered in a single document.

In the seventh and final step, the GP was asked to consider the findings of the pharmacist and to indicate whether or not each intervention was accepted. In cases where the GP chose not to follow the suggestions made, the GP was asked to provide the reason for not doing so. Finally, a copy of all interventions suggested by the pharmacist, together with the GP's responses, was inserted into the patient's medical chart for future reference.

\section{Guidelines}

To assess pharmacological treatment, a wide selection of national clinical guidelines and treatment guidelines from different scientific societies for the most common chronic diseases were identified.

Current Danish national guidelines were used in the assessment of the pharmacological treatment: Cardiology $^{8}$, hypertension ${ }^{9}$, anxiety ${ }^{10}$, unipolar depression $^{11}$, lower urinary tract symptoms ${ }^{12}$, acidrelated disorders ${ }^{13}$, chronic obstructive pulmonary disease (COPD) $)^{14}$, type 2 diabetes $^{15}$, asthma ${ }^{16}$, stroke $^{17}$, and osteoporosis. ${ }^{18}$

For diseases or conditions where no updated treatment guidelines were available, we used the recommendations given by the Danish Institute for Rational Pharmacotherapy, which is situated in the Danish National Board of Health and provides health care professionals with independent reviews of new compounds and studies ${ }^{19}$ as well as a national list of recommended drugs ${ }^{20}$, which is based on reviews of efficacy and safety of medicines and contains assessments of whether or not clinically relevant differences exist between analogue drugs.

The Summary of Product Characteristics, SmPC ${ }^{21}$ was consulted when general information about a specific drug was required, such as different dosage forms or adverse effects.

Lastly, specific strategies for discontinuation of certain types of drugs were identified, i.e. long-term treatment with benzodiazepines ${ }^{22}$, opioids ${ }^{23}$ or prednisolone. ${ }^{23}$ 


\section{Testing}

The model was tested in a pilot study by a study pharmacist (M.B.) during the period 16th May 2012 to 14th June 2012. Two GPs located in Copenhagen participated in the study, each providing complete lists of all registered patients. The lists of prescription drugs for each of the registered patients were manually perused in order to identify all patients using seven or more prescription drugs for regular use, i.e. not including drugs used on an 'as needed' basis. The cut-off value of seven or more drugs was arbitrary, but selected in order to identify complex medical patients. Among these patients, it was decided to randomly select fifty patients for medication review.

The time spent on each medication review by the study pharmacist and the GP was recorded. This included time spent on the entire process of the medication review from collection of information, identification of intervention, registration and reporting of suggestions, and the GP's consideration. Lastly, the GPs were asked to indicate their level of agreement with each intervention using a 5-point Likert scale (1-5; strongly agree, agree, neither agree nor disagree, disagree, strongly disagree).

\section{Approval}

The study was approved by the Danish Data Protection Agency. Approval from the Ethics Committee was not required according to Danish law.

\section{RESULTS}

Of 2,655 registered patients, 72 patients were eligible for inclusion. Of these, 50 were randomly selected to have medication review via a computer program (Excel). One of the selected patients died during the period between selection and medication review and was therefore replaced. The patients used a median of nine drugs for regular use (range, 7-16 drugs). Thirty-two patients (64\%) were women, and the mean age was 74 years (interquartile range 69-82 years).

The medication reviews led to 208 suggested interventions, with a range of one to eight interventions per patient. The mean time spent on a medication review by the study pharmacist was 27 min. (range 15-38 min.) and $13 \mathrm{~min}$. (range 2-35 min.) by the GPs.

\begin{tabular}{|c|c|c|c|}
\hline Category & Examples & $\begin{array}{c}n \\
\text { (\% of total) }\end{array}$ & $\begin{array}{c}\text { Acceptance } \\
\text { rate, \% }\end{array}$ \\
\hline \multicolumn{2}{|l|}{ All diagnose-related interventions } & $107(51)$ & 77 \\
\hline Missing clinical or laboratory data & $\begin{array}{l}\text { The most recent measured blood pressure in a patient who is receiving } \\
\text { antihypertensive treatment is } 17 \text { months old and it is therefore not possible to } \\
\text { assess the current treatment. }\end{array}$ & $38(18)$ & 82 \\
\hline $\begin{array}{l}\text { Change to another drug in order } \\
\text { to meet current guidelines }\end{array}$ & $\begin{array}{l}\text { A hypertensive patient is treated with a beta-blocker, ACE inhibitor or thiazide. } \\
\text { The patient has no co-morbidity like previous acute myocardial infarction } \\
\text { (AMI), heart failure or arrhythmias, why the beta-blocker is suggested } \\
\text { discontinued on transition to a calcium-antagonist. }\end{array}$ & $20(10)$ & 60 \\
\hline $\begin{array}{l}\text { Change of dosage in order to } \\
\text { meet current guidelines }\end{array}$ & $\begin{array}{l}\text { The daily dose of acetylsalicylic acid is suggested reduced from } 150 \mathrm{mg} \text { to } 75 \\
\mathrm{mg} \text { to avoid the increased risk of bleeding. }\end{array}$ & $14(7)$ & 86 \\
\hline $\begin{array}{l}\text { Add-on treatment in order to meet } \\
\text { current guidelines }\end{array}$ & $\begin{array}{l}\text { Addition of a statin in a patient who is at high risk of dying from cardiovascular } \\
\text { disease. }\end{array}$ & $23(11)$ & 74 \\
\hline $\begin{array}{l}\text { Discontinuation of current } \\
\text { treatment in order to meet current } \\
\text { guidelines }\end{array}$ & $\begin{array}{l}\text { A patient with an AMI back in } 2009 \text { is being treated with acetylsalicylic acid } \\
\text { together with clopidogrel. Clopidogrel is suggested discontinued since it is only } \\
\text { indicated for a period of } 12 \text { months after the AMI. }\end{array}$ & $12(6)$ & 83 \\
\hline \multicolumn{2}{|l|}{ All drug-related interventions } & $101(49)$ & 88 \\
\hline $\begin{array}{l}\text { Missing diagnosis (treatment not } \\
\text { indicated - treatment } \\
\text { discontinued) }\end{array}$ & $\begin{array}{l}\text { Treatment with a proton pump inhibitor (PPI) is suggested discontinued due to } \\
\text { lack of indication because the patient is no longer being treated with an } \\
\text { NSAID. }\end{array}$ & $47(23)$ & 79 \\
\hline Missing laboratory data & No laboratory data available despite massive potassium supplements. & $19(9)$ & 100 \\
\hline $\begin{array}{l}\text { Discontinuation/change in current } \\
\text { treatment (patient } \\
\text { characteristics/diagnoses) }\end{array}$ & $\begin{array}{l}\text { An opioid is suggested discontinued because the patient is experiencing } \\
\text { frequent falls. }\end{array}$ & $3(1)$ & 100 \\
\hline $\begin{array}{l}\text { Discontinuation/change in current } \\
\text { treatment (alarming laboratory } \\
\text { data) }\end{array}$ & $\begin{array}{l}\text { Bendroflumethiazide with potassium is suggested discontinued in a } \\
\text { hyperkalemic patient }\end{array}$ & $7(3)$ & 100 \\
\hline $\begin{array}{l}\text { Discontinuation/change in current } \\
\text { treatment (inappropriate } \\
\text { combination of drugs) }\end{array}$ & $\begin{array}{l}\text { Norvasc is suggested discontinued because the patient is already being } \\
\text { treated with a dose-dispensed amlodipine. }\end{array}$ & $4(2)$ & 100 \\
\hline $\begin{array}{l}\text { Discontinuation/change in current } \\
\text { treatment (adverse effects) }\end{array}$ & $\begin{array}{l}\text { A patient, who is being treated with two different laxatives, is experiencing } \\
\text { frequent diarrhea, why the treatment with laxatives is suggested discontinued. }\end{array}$ & $4(2)$ & 100 \\
\hline $\begin{array}{l}\text { Add-on treatment (adverse } \\
\text { effects) }\end{array}$ & $\begin{array}{l}\text { Add-on treatment with a laxative is suggested to a patient, who is experiencing } \\
\text { obstipation due to treatment with an opioid. }\end{array}$ & $6(3)$ & 67 \\
\hline $\begin{array}{l}\text { Change to alternate } \\
\text { drug/treatment (price) }\end{array}$ & $\begin{array}{l}\text { The prescription of tramadol formulated as a capsule is proposed changed to } \\
\text { tramadol formulated as tablets. }\end{array}$ & $8(4)$ & 100 \\
\hline $\begin{array}{l}\text { Change to alternate } \\
\text { drug/treatment (number of } \\
\text { dosages) }\end{array}$ & $\begin{array}{l}\text { Isosorbide dinitrate is changed to isosorbide mononitrate in order to reduce the } \\
\text { risk of development of tolerance and to reduce the number of daily dosages. }\end{array}$ & $3(1)$ & 100 \\
\hline
\end{tabular}




\begin{tabular}{|c|c|c|}
\hline ATC code & Nunber & $\%$ \\
\hline (C10) Lipid-modifying agents & 24 & 12 \\
\hline (C02-C03, C07-C09) Miscellaneous antihypertensive drugs & 24 & 12 \\
\hline (C03) Diuretics & 20 & 10 \\
\hline (N05) Psycholeptic drugs & 20 & 10 \\
\hline (A02) Drugs for acid-related disorders & 14 & 7 \\
\hline (B01) Antithrombotic agents & 14 & 7 \\
\hline (A11) Vitamins and (A12) mineral supplements & 12 & 6 \\
\hline (A10) Drugs used in diabetes & 9 & 4 \\
\hline (M01) Anti-inflammatory and antirheumatic products & 9 & 4 \\
\hline (A06) Laxatives & 8 & 4 \\
\hline (C07) Beta-blocking agents & 7 & 3 \\
\hline (C09) Agents acting on the renin-angiotensin system & 7 & 3 \\
\hline (N02) Analgesics & 6 & 3 \\
\hline (N06) Psychoanaleptic drugs & 5 & 2 \\
\hline (C02) Antihypertensive drugs & 4 & 2 \\
\hline (C08) Calcium channel blockers & 4 & 2 \\
\hline (C01) Cardiac therapy & 3 & 1 \\
\hline (R03) Drugs for obstructive airway diseases & 3 & 1 \\
\hline Various (B03, G03, G04, H01, H02, H03, J01, M05, P01) & 15 & 7 \\
\hline Total number of interventions & 208 & 100 \\
\hline
\end{tabular}

Overall, 171 of the 208 interventions (82\%) were accepted. The acceptance rate was comparable between the two GPs $(76 \%$ vs. $89 \%)$. Eight interventions $(4 \%)$ were rejected altogether. Twenty-nine interventions were neither accepted nor rejected; 18 interventions $(9 \%)$ because the responsibility for the treatment were believed to lie elsewhere and 11 interventions (5\%) either called for further examination or inquiry into the patient's condition before a decision could be made.

The diagnose-related and drug-related interventions are listed in Table 1. The intervention most commonly suggested was missing clinical/laboratory data, which was identified 38 times as a diagnose-related intervention and 19 times as a drug-related intervention. The most frequent absence of clinical data as diagnosisrelated interventions was measurements of blood pressure, which accounted for 14 (37\%) interventions, and laboratory measurements of lipid status, which accounted for $11(29 \%)$ interventions. As drug-related interventions, the most frequent absence of laboratory data was measurements of serum potassium in patients who received diuretics including high-dose thiazides and/or potassium supplements, which accounted for ten (53\%) interventions. Another frequent intervention was discontinuation of a drug due to lack of indication, which accounted for $23 \%$ of all interventions. In $79 \%$ of the cases, where discontinuation of a drug was proposed due to lack of indication, the GPs accepted the suggestions and attempted discontinuation. This led to 37 discontinuations among 26 patients. Of the 37 discontinuations, treatment with benzodiazepines accounted for 17 $(46 \%)$, treatment with a proton pump inhibitor (PPI) accounted for nine $(24 \%)$ and treatment with acetylsalicylic acid accounted for six (16\%).

Change to another drug in order to meet current guidelines was the category with the lowest acceptance rate. Out of eight rejected interventions, six were attributed to the GPs expecting that the responsibility for the treatment lay elsewhere.
In addition to the above interventions, the GPs were in 146 cases made aware that a diagnosis that was currently treated was not properly registered, i.e. the diagnosis was only found by review of the medical chart and was not included in the primary description of the patient. These interventions were not included in the total number of interventions.

The GPs' level of agreement with the suggested interventions was evaluated using a 5-point Likert scale. The responses were 'strongly agree' 39 (26\%), 'agree' 81 (54\%), 'neither agree nor disagree' $18(12 \%)$, 'disagree' $11(7 \%)$ and 'strongly disagree' $0(0 \%)$. As the GPs felt that their level of agreement was often evident from their written comments, the response rate for the Likert scale was only $72 \%$.

Table 2 shows the distribution of the drug classes most commonly involved in interventions, specified according to the second level of the Anatomical Therapeutic Chemical (ATC) classification system (24). The most frequently involved drug class was the lipid modifying agents (ATC, C10) which accounted for $24(12 \%)$ of the interventions. The majority of these $(n=15,63 \%)$, were lack of laboratory data, while five (21\%) interventions suggested changes to existing treatment in the form of add-on treatment in order to meet current guidelines. Additional frequently occurring ATC codes were diuretics (C03) and psycholeptics (N05), each accounting for $20(10 \%)$ interventions. The interventions dealing with diuretics were distributed among different intervention categories; six interventions due to missing laboratory data, three suggested discontinuations due to alarming laboratory data, four suggested discontinuations due to lack of indication, four suggested change of dosage due to supra-therapeutic dosage levels, two suggested add-on treatments in order to meet current guidelines and one intervention suggested discontinuation due to adverse effects. Eighteen of the interventions dealing with psycholeptics were suggestions of discontinuation because they were not indicated for long-term treatment. The remaining two suggested change to another drug in order to 
meet current guidelines. The miscellaneous category comprising $\mathrm{C} 02-\mathrm{CO} 3$ and $\mathrm{C} 07-\mathrm{C} 09$ represent the interventions related to missing measurements of blood pressure. These interventions were collected in this category to avoid double registration, as they could not be attributed a single drug class.

\section{DISCUSSION}

This study describes a practice model for pharmacists' medication review in a general practice setting. Upon testing, a median of four interventions were identified per patient. The interventions most often identified were missing clinical or laboratory data and suggestions to discontinue drug treatment due to lack of indication. The acceptance rate of the GPs was high.

The main strength of this study is the detailed description of the practice model, ensuring a comprehensive and systematic medication review. The model has been tested in a real-life setting and found to be useful to identify problems that were found relevant by the treating GP. The involvement of the GP allows interventions to be implemented directly. Furthermore, the use of GP data, such as medical charts and laboratory data enables the pharmacist to make suggestions on missing clinical and laboratory data. Overall, the GP setting provides an excellent opportunity to perform medication reviews. ${ }^{25-28}$ Lastly, the model can be used as described by any well-trained pharmacist with an in-depth knowledge of rational pharmacotherapy and treatment guidelines.

The primary limitation of the model is the lack of patient involvement. Patient interviews could potentially clarify many issues, such as use of overthe-counter medications, the presence of sideeffects not mentioned in the GP records, or whether the patient displays compliance issues. While patient interview could potentially lead to a more thorough medication review ${ }^{1}$, patient involvement would increase the time used per review considerably above the average 27 minutes spent by the pharmacist. As such, it is a trade-off between achieving in-depth reviews and being able to cover more patients per day. An example of a model including patient interview has been published by Lowe et al. ${ }^{26}$ Another limitation is that the GP setting infers that only drugs known to the GP are included, which leads to the risk of not all drugs taken by the patient being reviewed. Further, the two GPs volunteering to participate in the study might be more positive towards the suggestions made by the pharmacist or differ in other ways from the average GP. Lastly, a limitation to the model is that it was not developed through a standardized process (e.g. a Delphi process or similar). The model was developed by two pharmacists (A.P. and M.B.) from their experience in conducting medication review in the GP setting. The two pharmacists had an initial testing period to ensure standardization of the medication review and to generate the final model presented here.
It is important to emphasize that frequently cited tools for medical reviews, such as the STOPP \& START criteria, cannot stand alone or replace clinical judgment, as also pointed out by the authors of these tools. ${ }^{29}$ The STOPP \& START or Beers criteria $^{30}$, are aimed at specific diseases and provides explicit guidance about interventions. Thereby, they are somewhat simpler than our proposed model. However the coverage of these explicit criteria is not always optimal, i.e., quite many important drug-related problems fall outside their scope. In contrast to these criteria-based models, our model allows for a more in-depth review that to a higher degree allows specific patient characteristics to be taken into account. In the framework of the UK National Prescribing Centre for medication review ${ }^{1}$, our proposed model fits the purpose of the clinical medication review (to address issues relating to the patient's use of medicines in the context of their clinical condition), with the notable exception that it does not include direct patient contact and therefore might not be considered a 'full clinical medication review'.

When the practitioner disagree with a given recommendation, it is often because of some unknown (to the pharmacist) patient characteristic that renders the suggestion irrelevant for the specific patient, despite the suggestion following current guidelines etc. In our opinion, pharmacists should never aim at obtaining a 100\% acceptance rate, which would likely be a marker of the pharmacist not having questioned the medical treatment sufficiently.

An interesting finding is the number of interventions rejected due to the GP's opinion that the responsibility for the treatment lay elsewhere. As an example, a patient with diabetes and cardiovascular disease did not receive statin treatment, which the GP did not wish to correct, as the GP expected the hospital physician to manage this as a part of the ambulatory care. This highlights a principal weakness in the shared care model, involving multiple physicians, thereby rendering the single physician unable or unwilling to assume responsibility.

Another interesting finding is the use of in average 27 minutes on each review, which was longer than expected. This is largely explained by the insufficient diagnosis registration, as seen by the 146 cases where a drug was not accounted for by the list of diagnoses. This required the pharmacist to read larger portions of the medical charts. As such, the time needed per patient is largely dependent on the individual GP. Furthermore, the average time is expected to drop as the pharmacist has more experience with the model.

\section{CONCLUSIONS}

In the present paper, we have presented a model for pharmacists' medication review to be used in a GP setting. The model was tested and found to be workable. As stated initially, a debate on the practical approach towards pharmacists' medication review is needed. We therefore openly invite other 
pharmacist, as well as other clinicians, to comment and criticize our way of doing things, as well as provide descriptions on how they conduct medication review in their setting. Only by scrutinizing our daily routines can we improve upon the formula, hopefully resulting in better outcomes for the patients in our care.

\section{ACKNOWLEDGEMENTS}

The authors thank Anna Birna Almarsdottir for valuable comments on the manuscript.

\section{CONFLICT OF INTEREST}

The authors declare that they have no conflicts of interest relevant to this study.

Funding: The study was funded by the University of Southern Denmark.

\section{DESCRIPCIÓN DE UN MODELO DE PRÁCTICA PARA REVISIÓN DE LA MEDICACIÓN POR FARMACÉUTICO EN UNA CONSULTA DE MEDICINA GENERAL}

\section{RESUMEN}

Antecedentes: Las descripciones prácticas de los procedimientos utilizados para le revisión dela medicación por farmacéuticos son escasas. Objetivo: Describir un modelo de revisión de la medicación pro farmacéuticos diseñada para una consulta de medicina general.
Métodos: Se describe un modelo paso a paso. El modelo se basa en los datos de la historia clínica y de análisis clínicos. La revisión de la medicación se centra en los diagnósticos del paciente en lugar de en los medicamentos individuales. Las entrevistas a los pacientes no forman parte del modelo. El modelo se probó en un estudio piloto realizando revisiones de la medicación a 50 pacientes polimedicados (i.e., que recibían 7 o más medicamentos para uso habitual). Resultados: El modelo consiste en siete pasos principales. La información sobre el paciente y su tratamiento actual se recoge en los tres primeros pasos, seguidos de la identificación de posibles intervenciones, bien relacionadas con los diagnósticos, bien con los medicamentos en los pasos cuarto y quinto. Los pasos sexto y séptimo son relativos a la comunicación de las intervenciones y las consideraciones del médico. Se propusieron 208 intervenciones entre los 50 pacientes. La tasa de aceptación por le médico fue del $82 \%$. Las intervenciones más comunes fueron la falta de datos clínicos o de laboratorio $(\mathrm{n}=57 ; 27 \%)$ y los medicamentos que deberían ser discontinuados porque no tenían indicación $(\mathrm{n}=47 ; 23 \%)$. La mayoría de las intervenciones apuntaban a medicamentos cardiovasculares.

Conclusión: Hemos proporcionado una descripción de un abordaje práctico de la revisión de la medicación pro farmacéutico en una consulta de medicina general. El modelo se probó y se encontró que era utilizable, y proporcionaba revisiones de la medicación con altas tasas de aceptación.

Palabras clave: Servicios Farmacéuticos; Práctica Profesional; Farmacéuticos; Médicos Generales; Efectos Adversos de los Medicamentos y Reacciones Adversas; Farmacoterapia; Dinamarca

References

1. National Prescribing Centre. A guide to medication review. Available from: http://www.npc.nhs.uk/review medicines/intro/resources/agtmr web1.pdf (Accessed 9/11/2012).

2. Blenkinsopp A, Bond C, Raynor DK. Medication reviews. Br J Clin Pharmacol. 2012;74(4):573-580. doi: 10.1111/j.13652125.2012.04331.x

3. Cipolle RJ, Strand LM, Morley P. Pharmaceutical Care Practice: The Patient-Centered Approach to Medication Management. Third Edition ed. 2012. McGraw Hill Professional:

4. Graabaek T, Kjeldsen LJ. Medication reviews by clinical pharmacists at hospitals lead to improved patient outcomes: a systematic review. Basic Clin Pharmacol Toxicol. 2013;112(6):359-373. doi: 10.1111/bcpt.12062

5. Thomsen LA, Herborg H, Rossing $\mathrm{C}$. Modeller for medicingennemgang i den danske primære sundhedssektor [Models for medication review in the Danish primary health sector]. Version 1.1 ed. 2011. Pharmakon:

6. Gallagher P, Ryan C, Byrne S, Kennedy J, O'Mahony D. STOPP (Screening Tool of Older Person's Prescriptions) and START (Screening Tool to Alert doctors to Right Treatment). Consensus validation. Int J Clin Pharmacol Ther. 2008;46(2):72-83.

7. Hanlon JT, Schmader KE, Samsa GP, Weinberger M, Uttech KM, Lewis IK, Cohen HJ, Feussner JR. A method for assessing drug therapy appropriateness. J Clin Epidemiol. 1992;45(10):1045-1051.

8. Dansk Cardiologisk Selskab. NBV11 Den Nationale Kardiologiske Behandlingsvejledning, Maj 2011 [The National Cardiology Guideline]. Available from: http://cardio.dk/nbv (Accessed 23/4/2012).

9. Bang L, Bruun N, Christensen K, Ibsen H, Svendsen T. Hypertensio arterialis - behandlingsvejledning [Hypertensio Arterialis - Treatment Guideline]. Dansk Hypertensionsselskab; 2009.

10. Dansk Selskab for Almen Medicin. Klinisk Vejledning for Almen Praksis. Angsttilstande [Anxiety disorders]. 2010.

11. Dansk Selskab for Almen Medicin. Klinisk Vejledning for Almen Praksis. Unipolar Depression. [Unipolar Depression]. 2010.

12. Dansk Selskab for Almen Medicin. Klinisk Vejledning for Almen Praksis. Udredning og behandling af nedre urinvejssymptomer hos mænd og kvinder [Elucidation and treatment of lower urinary symptoms among male and female]. 2009.

13. Dansk Selskab for Almen Medicin. Klinisk Vejledning for Almen Praksis. Dyspepsi [Dyspepsia]. 2009.

14. Dansk Selskab for Almen Medicin. Klinisk Vejledning for Almen Praksis. KOL i almen praksis [COPD in general practice]. 2008. 
15. Dansk Selskab for Almen Medicin. Klinisk Vejledning for Almen Praksis. Guidelines for type 2-diabetes [Guidelines for type-2 diabetes]. 2011.

16. Porsbjerg C, Siersted H, Sidenius K, Hilberg O, Backer V. Astma: Behandling. [Asthma: Treatment]. Dansk Lungemedicinsk Selskab; 2009.

17. Dansk Selskab for Apopleksi. Referenceprogram for behandling af patienter med apopleksi [Guideline for treatment of patients with apoplexy]. 2009.

18. Dansk Knoglemedicinsk Selskab. Vejledning til udredning og behandling af osteoporose [Guideline for elucidation and treatment of osteoporosis]. 2009.

19. Institut for Rationel Farmakoterapi. Anmeldelser [Drug Reviews]. Available from: http://irf.dk/dk/anmeldelser/ (Accessed 18/7/2012).

20. Institut for Rationel Farmakoterapi. National Rekommandationsliste [National Recommendation List]. Available from: http://www.irf.dk/dk/rekommandationsliste/ (Accessed 24/4/2012).

21. European Medicines Agency. Summary of Product Characteristics (SPC). Available from: http://www.ema.europa.eu/ema/index.jsp?curl=pages/medicines/landing/epar search.jsp\&mid=WC0b01ac058001d125 (Accessed 26/6/2013).

22. Institut for Rationel Farmakoterapi. Benzodiazepin-nedtrapningsskemaer til praktiserende læger, praksismedarbejdere og patienter [A scheme for gradual reduction of benzodiazepines in general practice]. Available from: http://irf.dk/dk/publikationer/veiledninger/benzodiazepin nedtrapningsskemaer til praktiserende laeger.htm (Accessed 14/5/2012).

23. Institut for Rationel Farmakoterapi. Seponering [Drug Discontinuation]. Available from: http://www.irf.dk/dk/redskaber/seponering/ (Accessed 24/4/2012).

24. WHO Collaborating Centre for Drug Statistics Methodology. Structure and principles. Available from: http://www.whocc.no/atc/structure and principles/ (Accessed 18/7/2012).

25. Glintborg D. Medicingennemgang i almen praksis [Medication Review in General Practice]. Månedsskrift for Almen Praksis 2011;89:5-10.

26. Lowe CJ, Petty DR, Zermansky AG, Raynor DK. Development of a method for clinical medication review by a pharmacist in general practice. Pharm World Sci. 2000;22(4):121-126.

27. Chen TF, de Almeida Neto AC. Exploring elements of interprofessional collaboration between pharmacists and physicians in medication review. Pharm World Sci. 2007;29(6):574-576.

28. Morgado MP, Morgado SR, Mendes LC, Pereira LJ, Castelo-Branco M. Pharmacist interventions to enhance blood pressure control and adherence to antihypertensive therapy: Review and meta-analysis. Am J Health Syst Pharm. 2011;68(3):241-253. doi: 10.2146/ajhp090656

29. O'Mahony D, Gallagher P, Ryan C, Byrne S, Hamilton H, Barry P, O'Connor M, Kennedy J. STOPP \& START criteria: A new approach to detecting potentially inappropriate prescribing in old age. Eur Geriatr Med. 2010;1(1):45-51.

30. American Geriatrics Society 2012 Beers Criteria Update Expert Panel. American Geriatrics Society updated Beers Criteria for potentially inappropriate medication use in older adults. J Am Geriatr Soc. 2012;60(4):616-631. doi: 10.1111/j.1532-5415.2012.03923.x 